\section{Dental caries and endemic dental fluorosis in rural communities, Minas Gerais, Brazil}

\section{Cárie dentária e fluorose endêmica em distritos rurais de Minas Gerais, Brasil}

\section{Simone de Melo Costa'}

Mauro Henrique Nogueira Guimarães Abreu"

Andréa Maria Duarte Vargas"

Mara Vasconcelos"

\section{Efigênia Ferreira e Ferreira"}

\section{Lia Silva de Castilho"'I}

'Department of Dentistry at Universidade Estadual de Montes Claros Montes Claros (MG), Brazil.

"Department of Social and Preventive Dentistry of the School of Dentistry at Universidade Federal de Minas Gerais - Minas Gerais (MG), Brazil.

"'Department of Restorative Dentistry of the School of Dentistry at Universidade Federal de Minas Gerais - Minas Gerais (MG), Brazil.

Corresponding author: Simone de Melo Costa, Rua Dr. Valmor de Paula, 27, Vila Regina CEP 38400-198, Montes Claros, MG, Brasil. E-mail: smelocosta@gmail.com Financial support: National Council for Scientific and Technological Development (CNPq - Process n. 503.146/2003-0 e 57.7074/2008-3) and Fundo de Amparo ao Pesquisador de Minas Gerais (Fapemig - APQ-07438-07).

Conflict of interests: nothing to declare.

\section{Abstract}

It is observational, analytical and crosssectional aimed to evaluate the association between severity and prevalence of fluorosis and dental caries in rural communities with endemic dental fluorosis in the north state of Minas Gerais, Brazil, with fluoride concentrations in water up to $4.8 \mathrm{mg} / \mathrm{L}$. Data were collected by one examiner (intraexaminer kappa, 0.96 to 0,95 for caries and fluorosis) after toothbrushing. The study included 511 individuals aged $7-22$ years, categorized according to age: 7 - 9 years $(\mathrm{n}=227), 10$ to 12 years $(\mathrm{n}=153), 13$ to 15 years $(n=92), 16$ to 22 years $(n=39)$. For the diagnosis of dental caries used the criteria of the World Health Organization to measure indices DMFT. For fluorosis used the index Thylstrup and Fejerskov (TF), dichotomized according to prevalence ( $\mathrm{TF}=0$ and $\mathrm{TF}>0$ ) and severity ( $\mathrm{TF} \leq 4$ and $\mathrm{TF} \geq 5$ ). In the two younger groups, the DMFT and its decay component were higher in the group with more severe fluorosis $(\mathrm{p}<0.001)$. This association was not found among adolescents and adults ( $p>0.05$ ). The association was found between the conditions more severe fluorosis and caries in individuals under 12 years.

Keywords: Dental fluorosis. Dental Caries. Prevalence. Epidemiology. Public Health. Brazil 


\section{Resumo}

Trata-se de estudo transversal e analítico cujo objetivo foi avaliar a associação entre a prevalência e a gravidade da fluorose e da cárie dentária em municípios rurais com fluorose endêmica no norte do Estado de Minas Gerais, Brasil, com concentração de flúor nas águas de até 4,8 $\mathrm{mg} / \mathrm{L}$. Os dados foram coletados por um examinador (Kappa intra examinador, 0,96 para fluorose e 0,95 para cárie) após escovação dentária. Participaram do estudo 511 indivíduos, com idades de 7 a 22 anos, categorizados conforme faixa etária: 7 a 9 anos $(\mathrm{n}=227), 10$ a 12 anos $(\mathrm{n}=153)$, 13 a 15 anos (n = 92), 16 a 22 anos $(n=39)$. Para o diagnóstico da cárie dentária, utilizaram-se os critérios da Organização Mundial da Saúde - OMS para a mensuração do índice CPO-D. Para a fluorose utilizou-se o índice de Thylstrup e Fejerskov (TF), dicotomizado segundo a prevalência ( $\mathrm{TF}=0 \mathrm{e} \mathrm{TF}>0$ ) e gravidade ( $\mathrm{TF} \leq 4 \mathrm{e} \mathrm{TF} \geq 5$ ).Nos dois grupos mais jovens, o CPO-D e seu componente cariado foram maiores no grupo com fluorose mais grave $(\mathrm{p}<0,001)$. Essa associação não foi identificada entre os adolescentes e adultos ( $p>0,05)$. A associação mais grave entre as condições cárie e fluorose foi encontrada em indivíduos com até 12 anos.

Palavras-chave: Fluorose dentária. Cárie dentária. Prevalência. Epidemiologia. Saúde Pública. Brasil.

\section{Introduction}

Much is known about the effect of fluoride on dental caries prevention and control. The first consistent evidence came from the classic study conducted by Dean et al. ${ }^{1}$ in the United States, in the 1940s. However, the first suspected association between fluoride and human health was related to dental fluorosis, based on the observations made in the beginning of the $20^{\text {th }}$ century ${ }^{2}$, in the 1930 s.

Since the studies conducted by Richards et al. ${ }^{3}$, the possibility of benefiting from the reduction in dental caries levels without being affected by fluorosis has also been known, through the controlled addition of fluoride to the public water supply.

The acceptable level of fluoride in drinking water was one part per million (ppm), a value originally established according to the aesthetic acceptability of fluorosis, rather than the preventive aspects of fluoride action on the teeth ${ }^{1}$. This discovery is the basis of water fluoridation, considered to be an important public health measure to control dental caries to this day.

The first studies on fluoride, fluorosis and dental caries pointed to a direct relationship between fluoride and fluorosis and an inverse relationship between fluoride and dental caries. However, the association between fluorosis, especially when it is endemic, and dental caries has been scarcely investigated. More recent studies have suggested that enamel defects in teeth with hypoplasia, including severe dental fluorosis, could promote dental caries ${ }^{4-6}$. In the northern part of the state of Minas Gerais, Brazil, among certain rural communities, a study observed the presence of endemic fluorosis due to the continuous consumption of water from natural sources with a high fluoride content above what is recommended $(1.5 \mathrm{mg} / \mathrm{L})^{7}$.

Considering the fact that knowledge about the association between dental caries and endemic fluorosis has not been extensively researched in epidemiological studies, the present study aimed to assess the association between the prevalence and severity of fluorosis and dental caries, in rural cities with endemic fluorosis, in the northern part of the state of Minas Gerais, Brazil. 


\section{Methods}

A cross-sectional analytical study was performed in 2006. A total of 511 individuals aged between seven and 22 years were assessed. This age group was selected due to their continuous exposure to excessive fluoride found in the drinking water of deep artesian wells, in the northern part of the state of Minas Gerais. Artesian wells were used as an alternative against droughts by communities living in this impoverished area, between 1978 and 1998 , and as the only water supply resource, resulting in endemic fluorosis ${ }^{8}$ caused by the presence of fluorite in the soil.

All individuals who were present at the place of examination were tested, thus characterizing a convenience sample. None of them used fixed orthodontic braces. Study participants lived in 11 rural communities with endemic fluorosis resulting from the consumption of water with a high fluoride content. A study conducted in this region found a fluoride concentration in the water of up to $4.8 \mathrm{mg} / \mathrm{L}^{7}$, higher than the concentration $(1.5 \mathrm{mg} / \mathrm{L})$ considered as adequate for human health ${ }^{9}$. In addition, the high temperatures in this area result in greater water consumption, which could have contributed to endemic fluorosis in the community.

The clinical examination was performed by only one previously trained researcher, with an excellent intra-examiner agreement for fluorosis and dental caries (kappa $=0.96$ and 0.95 , respectively) in previously defined places (farms, schools, health units in rural areas), under natural lighting conditions, with previous tooth brushing and the help of gauze pads to dry teeth.

The diagnosis offluorosis was made according the following criteria: presence of enamel opacity with diffuse distribution, with an aspect that varies from small white stripes to extensive opaque areas in the enamel, considering the presence of homologous teeth, regardless of the severity of each of them ${ }^{10}$. The differential diagnosis between dental caries and fluorosis made in severe cases was based on the presence of soft dental tissue on the cavity floor or wall and the presence of surface demineralization.
The Thylstrup and Fejerskov Index $(\mathrm{TF})^{10}$ was used to diagnose fluorosis, assessed on all surfaces of all teeth ${ }^{11}$. This index follows an analogical-ordinal scale with nine scores, varying from zero (without fluorosis) to nine (severe fluorosis). The score provided by each tooth was based on the surface most affected by fluorosis. The scores from one to four indicate an increase in enamel opacity levels, although without loss of enamel structure. In contrast, scores from five to nine show the loss of dental enamel, where the higher the score, the greater the severity ${ }^{12}$.

The TF variable was dichotomized by prevalence ( $\mathrm{TF}=0$ and $\mathrm{TF}>0$ ) and severity (TF from 0 to 4 and TF higher than 4) as in the study conducted by Wondwossen et al. ${ }^{13}$, considering enamel defect as a factor that contributes to dental caries development.

The DMFT index (decayed, missing and filled teeth) for permanent dentition was used to determine the prevalence of dental caries, where each tooth assessed was coded according to the World Health Organization (WHO) criteria ${ }^{14}$.

The analysis was made considering four distinct groups, according to age group: 7 to 9 years ( $n=227), 10$ to 12 years $(n=153), 13$ to 15 years $(n=92)$, and 16 to 22 years $(n=39)$. All individuals examined lived in the rural districts during the period of risk of onset of fluorosis, i.e. they had consumed water with a high fluoride content between the ages of zero and six years.

The data obtained were input into the SPSS statistical software, version 18.0. A descriptive univariate statistical analysis was performed. The DMFT variables and their components did not show a normal distribution (KolmogorovSmirnov test with Lilliefors correction with $\mathrm{p}<0.001$ ). Consequently, Mann-Whitney tests were used to associate median values of DMFT indices and their components among the different age groups with the prevalence and severity of fluorosis, considering a significance level of $5 \%(p<0.05)$. This research project was approved by the Research Ethics Committee of the Universidade Federal de Minas Gerais UFMG (Official Opinion 0260-06). 


\section{Results}

With regard to dental caries, the highest prevalence was found in the 16 to 22 year age group, which included $82.05 \%$ of the individuals affected (Table 1). The mean values and standard deviation $( \pm$ SD $)$ and median DMFT values were assessed in the different age groups, with a mean of $0.67( \pm 1.33)$ and median of 0.00 for participants aged between 7 and 9 years; $1.38( \pm 2.02)$ and 0.00 for those aged between 10 and 12 years; $3.30( \pm 3.22)$ and 3.00 for those aged between 13 and 15 years; and $6.16( \pm 5.32)$ and 4.50 for those aged between 16 and 22 years.

The diagnosis of presence of fluorosis was confirmed in the majority of individuals, in all age groups studied (Table 1). With regard to the level of severity, fluorosis with a TF $\geq 5$ was diagnosed in $19.8 \%$ of children aged between 7 and 9 years; in $34.6 \%$ of those aged between 10 and 12 years; in $46.7 \%$ of those aged between 13 and 15 years; and in $48.7 \%$ of those aged between 16 and 22 years (Table 2). From 7 to
9 years of age, the TF value most frequently found was $\mathrm{TF}=1(17.2 \%)$; from 10 to 12 years, $\mathrm{TF}=5(10.5 \%)$; from 13 to 15 years, $\mathrm{TF}=6(13 \%)$; and 16 years or more, $\mathrm{TF}=7(17.9 \%)$.

The association between median DMFT values and the presence or absence of fluorosis could be observed in this study. Among participants aged up to 12 years, the median DMFT was 0.00 , both in the presence or absence of fluorosis ( $p>0.05)$. Among adolescents aged from 13 to 15 years, this value was 4.00 in the presence of fluorosis and 2.00 in the absence of fluorosis ( $p>0.05$ ); and among those aged 16 years or more, this value was 5.50 and 4.50 ( $p>0.05$ ) respectively. The median values of DMFT and their components were associated with the presence and severity of fluorosis, according to the different age groups of individuals (Table 3 ). In the younger age groups, from 7 to 9 years and from 10 to 12 years, the greater severity of fluorosis was associated with higher DMFT and with the decayed component.

Table 1 - Distribution of individuals according to prevalence of fluorosis (TF $\geq 1$ ) and dental caries (DMFT $\geq 1$ ) at different ages ( $7-22$ years). Rural communities of Minas Gerais with endemic fluorosis. Brazil, 2006.

Tabela 1 - Distribuição dos indivíduos conforme prevalência de fluorose (TF $\geq 1$ ) e cárie dentária $(C P O-D \geq 1)$ nas diferentes faixas etárias (7 a 22 anos). Distritos rurais de Minas Gerais com fluorose endêmica. Brasil, 2006.

\begin{tabular}{lccccc}
\hline \multirow{2}{*}{ Age (years) } & \multirow{2}{*}{$\mathrm{n}$} & \multicolumn{2}{c}{ Prevalence of fluorosis } & \multicolumn{2}{c}{ Prevalence of dental caries } \\
\cline { 3 - 6 } & & $\mathrm{n}$ & $\%$ & $\mathrm{n}$ & $\%$ \\
\hline $7-9$ & 227 & $153^{*}$ & 67.4 & 72 & 31.7 \\
$10-12$ & 153 & 96 & 62.7 & 61 & 39.9 \\
$13-15$ & 92 & $54^{* *}$ & 58.7 & 64 & 69.6 \\
$16-22$ & 39 & $26^{* *}$ & 66.7 & 32 & 82.0 \\
\hline
\end{tabular}

*2 missing; **1 missing

*2 perdas; ${ }^{* * 1}$ perda.

Table 2 - Distribution of individual according to severity of fluorosis in different age groups (7 - 22 years). Rural communities of Minas Gerais with endemic fluorosis. Brazil, 2006.

Tabela 2 - Distribuição dos indivíduos conforme gravidade de fluorose nas diferentes faixas etárias ( 7 a 22 anos). Distritos rurais de Minas Gerais com fluorose endêmica. Brasil, 2006.

\begin{tabular}{lccccc}
\hline \multirow{2}{*}{ Age (years) } & \multirow{2}{*}{$\mathrm{n}$ total } & \multicolumn{2}{c}{$\mathrm{TF} \leq 4$} & \multicolumn{3}{c}{$\mathrm{TF} \leq 5$} \\
\cline { 2 - 6 } & & $\mathrm{n}$ & $\%$ & $\mathrm{n}$ & $\%$ \\
\hline $7-9^{*}$ & 227 & 180 & 79.3 & 45 & 19.8 \\
$10-12$ & 153 & 100 & 65.4 & 53 & 34.6 \\
$13-15^{* *}$ & 92 & 48 & 52.2 & 43 & 46.7 \\
$16-22^{* *}$ & 39 & 19 & 48.7 & 19 & 48,7 \\
\hline
\end{tabular}

*2 missing; **1 missing.

*2 perdas; ${ }^{* *} 1$ perda 
Table 3 - Distribution of mean (standard deviation), median DMFT and its components in individuals of different ages (7 to 22 years) according to the presence of fluorosis and severity. Rural communities of Minas Gerais, Brazil. 2006.

Tabela 3 - Distribuição dos valores médios (desvio padrão), medianos do CPO-D e seus componentes nos indivíduos em diferentes faixas etárias (7 a 22 anos) de acordo com presença de fluorose e gravidade. Distritos rurais de Minas Gerais, Brasil. 2006.

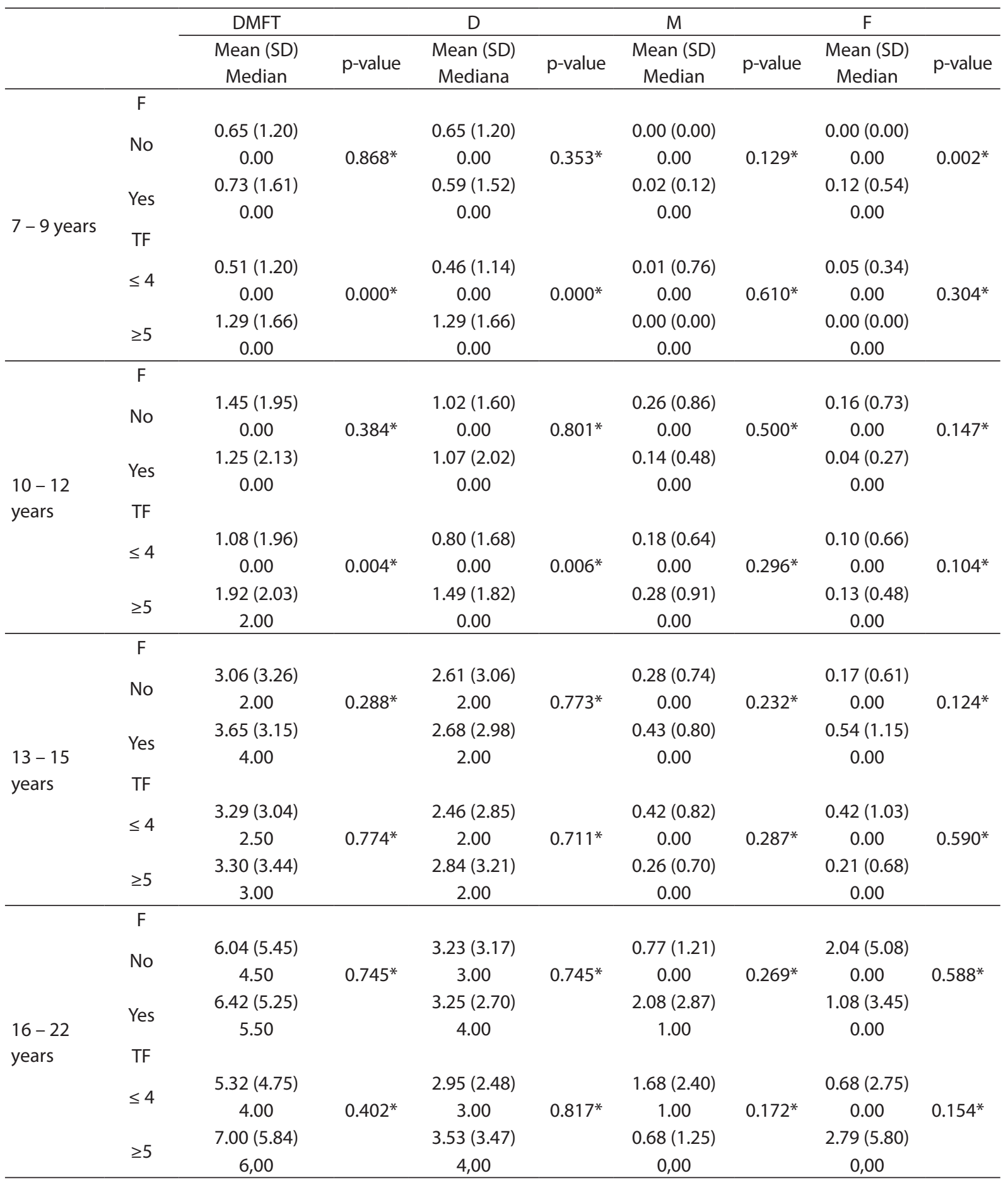

*Mann-Whitney's test; CPOD: Decayed/Missing/Filled Teeths index.; DP: standard deviation; F: fluorosis; TF: severity.

*Teste de Mann-Whitney; CPOD: Índice de Dentes 'Cariados, Perdidos e Obturados.; DP: desvio padräo; F: fluorose; TF: gravidade. 


\section{Discussion}

Dental caries and fluorosis are oral health problems that have been studied together, aiming to seek associations between these conditions ${ }^{15}$. However, studies that have dealt with the occurrence of dental caries among population groups that had endemic fluorosis in different parts of the world showed controversial results ${ }^{13,15,16}$. Consequently, there is no consensus on whether dental fluorosis increases, decreases or has no effect on the risk of cavities ${ }^{17}$. More studies that seek scientific evidence between dental caries and fluorosis are thus required, especially in countries that that have endemic dental fluorosis.

In the present study, the mean and median DMFT between the ages of 7 and 9 years were low, 0.67 and 0.00 respectively, both in the presence and absence of fluorosis. Researchers considered that the lower number of permanent teeth in this age group could have contributed to a low DMFT. Other studies showed a low DMFT for the ages of 6 and 7 years, such as the study conducted by Almerich-Silla et al. ${ }^{15}$, which had a mean DMFT of 0.48 in children of Western Sahara, in Northern Africa.

The mean and median values of DMFT in individuals aged between 10 and 12 years in rural districts of northern Minas Gerais with endemic fluorosis were low, 1.38 and 0.00 respectively. In a survey known as SB Brasil (Oral Health-Brazil) in 2002 - 2003, individuals aged 12 years and living in the Southeast region had a mean DMFT of 2.30 and a median DMFT of 1.00, whereas these values were 2.78 and 2.00 in Brazil, respectively ${ }^{18}$. Consequently, the DMFT values found in the present study were lower than the results observed in the Southeast region and Brazil.

The values found in this study are also in agreement with the goals proposed by the World Health Organization (WHO) for 2000 $(\text { DMFT }<3.00)^{18}$. The low value of DMFT is in agreement with other studies that have reported a reduction in the occurrence of caries in Brazil and in many countries ${ }^{19}$.

Studies in several parts of the world identified the mean DMFT in regions with a high fluoride content in the water supply. In Iran, a study conducted with adolescents aged from 11 to 16 years showed a DMFT of $1.8( \pm 1.73)^{20}$. In Ethiopia, among individuals aged between 12 and 15 years, the mean DMFT was 1.2 for areas with mean fluoride concentrations between 0.3 and $2.2 \mathrm{mg} / \mathrm{L}$. In areas with concentrations varying between 10 and $14 \mathrm{mg} / \mathrm{L}$, the mean DMFT value was $1.8^{12}$. In Lithuania, among individuals aged 12 years, the mean DMFT was $2^{15}$. In Mexico, among adolescents aged from 12 to 15 years, this mean was $1.5( \pm 1.7)^{21}$. In Western Sahara, this mean was 0.48 in children aged from 6 to 7 years and 1.69 in those aged from 11 to 13 years ${ }^{14}$.

With regard to the presence of fluorosis, individuals aged between 16 and 22 years had a higher prevalence of fluorosis (66.7\%). The lowest TF scores (from 0 to 4 ) were those most frequently identified in all age groups, with the exception of individuals aged 16 years or more, who had the same proportions in the $\mathrm{TF} \leq 4$ and $\mathrm{TF} \geq 5$ categories. In terms of the highest TF scores found in individuals aged more than 16 years, one hypothesis is that fluorosis would cause the dental structure to be more porous, resulting in the erosion of brittle enamel. With the passing of time, the masticatory force itself can promote erosion and more enamel defects can be observed in a progressive scale. The carious lesion also has a progressive evolution. It is possible that certain lesions diagnosed as carious are in areas where there used to be a fluorotic lesion, no longer identified during examination. In another study conducted with 213 individuals living in endemic areas of Northern Minas Gerais in 2002, the mean prevalence of $\mathrm{TF} \geq 4$ was $65 \%^{8}$

The association between DMFT and fluorosis revealed that, in the two youngest age groups (from 7 to 9 years and from 10 to 12 years), the DMFT value and its decayed component were higher in the group with most severe fluorosis than in that without fluorosis/with less severe fluorosis $(\mathrm{p}<0.01)$. This association was not identified among adolescents aged 13 years or more and 
adults ( $p>0.05)$. Although the results show a significant association between dental caries and fluorosis in the 7 to 9 year and 10 to 12 year age groups, this finding must be viewed with caution, as the sample did not show a great variation in terms of caries, i.e. it showed a high percentage of individuals without caries, especially in these age groups. On the other hand, the smaller sample size of the oldest age groups could have interfered with the results of the association between dental caries and fluorosis for these groups $(\mathrm{p}<0.05)$. The smaller sample of individuals aged from 16 to 22 years is justified by the fact that many adolescents did not live in the area due to their inclusion in the job market, in the city center or another location.

In the youngest age group, there was a statistically significant difference between the filled component of the DMFT and the presence of fluorosis $(\mathrm{p}<0.05)$. Researchers considered that the higher number of filled surfaces in individuals with fluorosis may not have resulted from dental caries exclusively, but also from dental enamel imperfections caused by fluorosis.

Other studies have analyzed the association between fluorosis and dental caries. The prevalence of caries was significantly higher among children with severe fluorosis, suggesting that this condition could increase susceptibility to dental caries ${ }^{14}$. The prevalence of caries was associated with a moderate to high level of severity of dental fluorosis in studies conducted in $\operatorname{Iran}^{20}$, Ethiopia $^{12}$, Mexico $^{21}$ and Western Sahara ${ }^{14}$. However, in a study conducted in Lithuania ${ }^{15}$, this association was not observed. The association between caries and severe fluorosis could be partly explained by the presence of enamel hypoplasia, which creates small depressions that serve as the basis for biofilm retention. This enamel defect affects the dental structure, which could lead to a higher probability of the onset and development of dental caries ${ }^{12,14}$.

One of the limitations of the present study was that it assessed only one factor (presence of fluorosis) associated with dental caries. Consequently, its findings must be viewed with caution, considering the fact that the multifactorial nature of caries involves biological, social and psychological factors. In addition, the cross-sectional design of the study prevents the assessment of causality. Another limitation refers to the convenience sample design, which does not guarantee that the sample is representative of the population. This sampling process is justified by the fact that it was performed in a rural area, in small communities with limited access. Researchers selected places close to clusters of homes because it was difficult to reach these homes. All individuals present at the place of examination were assessed. The limitation of the non-parametric statistical analysis for extrapolation and conclusions of this study should be emphasized, as the rural communities studied are not parameters for a population, i.e. the non-parametric test of hypothesis considered a particular distribution of the population studied.

\section{Conclusion}

The mean and median DMFT values found in individuals aged from 10 to 12 years living in rural districts of Northern Minas Gerais, Brazil, with endemic fluorosis were lower than the values observed in the national epidemiological survey conducted with individuals aged 12 years (SB-Brasil 2002/2003) ${ }^{18}$. However, an association between dental caries conditions and more severe fluorosis was found in those aged up to 12 years. This statistically significant association suggests that more severe fluorosis can increase susceptibility to dental caries. 


\section{References}

1. Dean HT, Jay P, Arnold FA, Elvove E. Domestic Water and dental caries. Public Health Rep 1942; 57(32): 1555-94.

2. Churchill HV. Ocurrence of Fluorides in Some Waters of the United States. Industrial Engineering Chem 1931; 23(9): 996-8.

3. Richards LF, Westmoreland WW, Tashiro M, Mckay CH, Morrison JT. Determining Optimum fluoride Levels for Community water supplies in Relation to temperature. J Am Dent Assoc 1967; 74(3): 389-97.

4. Kanchanakamol U, Tuongratanaphan S, Lertpoonvilaikul W, Chittaisong C, Pattanaporn D, Navia JM et al. Prevalence of developmental enamel defects and dental caries in rural pre-school Thai children. Community Dent Health 1996; 13(4): 204-7.

5. Montero MJ, Douglass JM, Mathieu GM. Prevalence of dental caries and enamel defects in Connecticut Head Start children. Pediatr Dent 2003; 25(3): 235-9.

6. Ribeiro AG, Oliveira AF, Rosenblatt A. Cárie precoce na infância: prevalência e fatores de risco em pré-escolares, aos 48 meses, na cidade de João Pessoa, Paraíba, Brasil. Cad Saúde Pública 2005; 21(6): 1695-700.

7. Ferreira EF, Vargas AMD, Castilho LS, Velásquez LNM, Fantinel LM, Abreu MHNG. Factors Associated to Endemic Dental Fluorosis in Brazilian Rural Communities. Int J Environ Res Public Health 2010; 7(8): 3115-28.

8. Velásquez LNM, Fantinel LM, Ferreira EF, Castilho LS. Dental fluorosis endemism related to natural groundwater contamination by fluorine in Mid São Francisco basin, Minas Gerais State, Brazil. Fourth International Conference on Safe Water 2006, Rio de Janeiro. Safe Water 2006, p.1-21. UFMG, Belo Horizonte, Brazil.

9. World Health Organization. Water Sanitation and Health. WHO: Geneva, Switzerland, 2010. Disponível em http://www.who.int/ water_sanitation_health/en/ [Acessado em 25 de maio de 2010].

10. Thylstrup A, Fejerskov O. Clinical appearance of dental fluorosis in permanent teeth in relation to histological changes. Community Dent Oral Epidemiol 1978; 6: 315-28.

11. Adelário AK, Vilas-Novas LF, Castilho LS, Vargas AMD, Ferreira EF, Abreu, MHNG. Accuracy of the Simplified Thylstrup \& Fejerskov Index in Rural Communities with Endemic Fluorosis. Int J Environ Res Public Health 2010; 7(3): 927-37.
12. Fejerskov O, Manji F, Baelum V, Moller IJ. Dental fluorosis. A handbook for health workers. Copenhagen: Munksgaard; 1988.

13. Wondwossen F, Astrom AN, Bjorvatn K, Bardsen A. The relationship between dental caries and dental fluorosis in areas with moderate- and high-fluoride drinking water in Ethiopia. Community Dent Oral Epidemiol 2004; 32(5): 337-44.

14. World Health Organization, Oral health surveys - basic methods. 4th edn. Geneva: World Health Organization; 1997; 41-2.

15. Almerich-Silla JM, Montiel-Company JM, Ruiz-Miravet A. Caries and dental fluorosis in a western Saharan population of refugee children. Eur J Oral Sci 2008; 116(6): 512-7.

16. Narbutaite J, Vehkalahti MM, Mileuviene S. Dental fluorosis and dental caries among 12-yr-old children from high- and low-fluoride areas in Lithuania. Eur J Oral Sci 2007; 115(2): 137-42.

17. Cunha-Cruz J, Nadanovsky P. Dental fluorosis increases caries risck. J Evid Based Dent Pract 2005; 5(3): 170-1.

18. Brasil. Ministério da Saúde. Secretaria de Atenção à Saúde. Departamento de Atenção Básica. Coordenação de Saúde Bucal. Projeto SB Brasil 2003. Condições de saúde bucal da população brasileira: 2002-2003. Resultados principais. Brasília: Ministério da Saúde; 2004.

19. Crosato-Michel E, Barbieri DB, Biazevic MGH, Correia LD. Condição de saúde bucal e autopercepção de fluorose dental: um estudo de base populacional no Sul do Brasil, 2003. RPG Rev Pós Grad 2007; 13(4): 353-7.

20. Ramezani GHH, Valaei N, Eikani H. Prevalence of DMFT and fluorosis in the students of Dayer City (Iran). J Indian Soc Pedo Prev Dent 2004; 22(2): 49-53.

21. Loyola APP, Márquez AI, Rodríguez JPL, Maupome G, Corona MLM, Solis CEM. Dental Fluorosis in 12and 15-Year-Olds at High Altitudes in Above-Optimal Fluoridated Communities in Mexico. J Public Health Dent 2008; 68(3): 163-6.

Received on: $12 / 13 / 10$

Final version presented on: 12/20/11 Accepted on: 02/16/12 